\title{
Discrete reduction patterns of parvalbumin and calbindin D-28k immunoreactivity in the dorsal lateral geniculate nucleus and the striate cortex of adult macaque monkeys after monocular enucleation
}

\author{
INGMAR BLÜMCKE, ${ }^{1}$ EDUARDO WERUAGA, ${ }^{1}$ SANDOR KASAS, ${ }^{1}$ \\ ANITA E. HENDRICKSON, ${ }^{2}$ AND MARCO R. CELIO ${ }^{1}$ \\ ${ }^{1}$ Institute of Histology and General Embryology, University of Fribourg, Rte. A. Gockel, CH-1705 Fribourg, Switzerland \\ ${ }^{2}$ Department of Biological Structure and Ophthalmology, SM-20, University of Washington, Seattle
}

(ReCEIVEd December 3, 1992; ACCEPTED May 19, 1993)

\begin{abstract}
We analyzed the immunohistochemical distribution of the two calcium-binding proteins, parvalbumin (PV) and calbindin D-28k (CB), in the primary visual cortex and lateral dorsal geniculate nucleus (dLGN) of monocularly enucleated macaque monkeys (Macaca fascicularis and Macaca nemestrina) in order to determine how the expression of PV and CB is affected by functional inactivity. The monkeys survived 1-17 weeks after monocular enucleation. The distribution pattern of each of the proteins was examined immunocytochemically using monoclonal antibodies and compared with that of the metabolic marker cytochrome oxidase $(\mathrm{CO})$. We recorded manually the number of immunostained neurons and estimated the concentration of immunoreactive staining product using a computerized image-acquisition system. Our results indicate a decrease of approximately $30 \%$ in the labeling of PV-immunoreactive (ir) neuropil particularly in those layers of denervated ocular-dominance columns receiving the geniculocortical input. There was no change in the number of PV-ir neurons in any compartment irrespective of the enucleation interval. For CB-ir, we found a $20 \%$ decrease in the neuropil labeling in layer $2 / 3$ of the denervated ocular-dominance columns. In addition, a subset of pyramidal CB-ir neurons in layers 2 and $4 B$, which are weakly stained in control animals, showed decreased labeling. In the dLGN of enucleated animals, PV-ir and CB-ir were decreased only in the neuropil of the denervated layers.

From these results, we conclude that cortical interneurons and geniculate projection neurons still express PV and CB in their cell bodies after disruption of the direct functional input from one eye. The only distinct decrease of $\mathrm{PV}$ and $\mathrm{CB}$ expression is seen in axon terminals from retinal ganglion cells in the $\mathrm{dLGN}$, and in the axons and terminals of both geniculocortical projection cells and cortical interneurons in the cerebral cortex.
\end{abstract}

Keywords: Calcium-binding proteins, Cytochrome oxidase, Visual deprivation, Neuroanatomy, Primates

\section{Introduction}

Parvalbumin (PV) and calbindin D-28k (CB), two closely related intracellular calcium-binding proteins, may be involved in control and modulation of intracellular $\mathrm{Ca}^{2+}$ in distinct nerve cell populations (for reviews see Andressen et al., 1993; Baimbridge et al., 1992; Braun, 1990). Both proteins bind intracellular free $\mathrm{Ca}^{2+}$ in a micromolar range, which suggests either that they have physiologically important storage and buffering properties (Chard et al., 1991; Köhr et al., 1991) or that they mediate intracellular $\mathrm{Ca}^{2+}$ fluxes (Williams, 1992). PV and CB occur in different types of nerve cells in the primate neocortex (Blümcke

Reprint requests to: Ingmar Blümcke, Institute of Histology and General Embryology, University of Fribourg, Rte. A. Gockel, CH-1705 Fribourg, Switzerland. et al., 1990; DeFelipe et al., 1989, 1990; Lewis \& Lund, 1990; VanBrederode et al., 1990; Williams et al., 1992). In the adult cortex, the majority of these neurons use gamma-aminobutyric acid (GABA) as their neurotransmitter (Celio, 1986; DeFelipe \& Jones, 1992; Hendry et al., 1989; VanBrederode et al., 1990). VanBrederode et al. (1990) have demonstrated that very few GABAergic neurons contain both $\mathrm{PV}$ and $\mathrm{CB}$, indicating that these mark specific subsets of interneurons. Whercus the occurrence of PV is restricted to GABAergic neurons, CB antibodies also lightly label some non-GABAergic pyramidal neurons (DeFelipe \& Jones, 1992; Ferrer et al., 1992; Hendrickson et al., 1991; Séquier et al., 1990; VanBrederode et al., 1990).

In mammals, PV and CB highlight different functional compartments of the central visual pathways (Celio et al., 1986; Jones \& Hendry, 1989; Mize et al., 1992b). The compartments containing high levels of PV are metabolically very active as is 
indicated by their high levels of cytochrome oxidase (CO) activity (Blümcke et al., 1990; VanBrederode et al., 1990), and CB immunoreactivity occurs in an almost interdigitating pattern with them (Celio et al., 1986; Hendry \& Carder, 1992; Jones \& Hendry, 1989; Spatz et al., 1992). Although the physiological tasks of PV and CB remain uncertain, their ability to mediate $\mathrm{Ca}^{2+}$ signals prompted the proposal of their involvement in the control of neuronal activity (Celio, 1990; Kawaguchi et al., 1987). Therefore, we were interested in studying the effect of silencing the central visual pathway on the expression of both calcium-binding proteins, $\mathrm{PV}$ and $\mathrm{CB}$, within the dorsal lateral geniculate nucleus (dLGN) and the primary visual cortex (area 17). For this we used tissue from monocularly enucleated macaque monkeys, an established model for studying the change of expression of distinct molecules after functional inactivation (Hendry, 1991; Hendry \& Carder, 1992; Hendry \& Jones, 1986, 1988; Mize \& Luo, 1992; Tigges \& Tigges, 1991; Wiesel \& Hubel, 1965; Wong-Riley \& Carroll, 1984). We expected to see a decrease in the expression of both proteins in the chain of the denervated neurons projecting to the visual cortex, as well as within denervated local-circuit neurons in the cortex. Surprisingly, however, only the concentration of both proteins in the terminals of projection neurons was decreased, whereas the perikaryal expression of either PV or CB was relatively well preserved.

\section{Materials and methods}

Tissue blocks from the primary visual cortex (area 17 or V1) of seven adult Old World monkeys (Macaca fascicularis or Macaca nemestrina) were included in this study. Cortical tissue blocks were all taken from the opercular surface which represents the central 6-8 deg of the visual field; peripheral representations were not studied. The monkeys used are described in Table 1. Although the exact age was not known for all animals, judging by weight and dentation pattern, all were 5 years or older. In the experimental animals, the globe was enucleated under surgical halothane anesthesia. The lids were sutured closed after all bleeding was stopped. Recovery was uneventful in all cases.

\section{Immunohistochemistry}

For the perfusion, the animals were deeply anesthetized with ketamine and barbiturate and perfused transcardially with $0.1 \mathrm{M}$ phosphate buffer containing $0.1 \%$ paraformaldehyde (PFA). After removal of one occipital hemisphere for other studies, the brain was perfused in situ with $4 \%$ PFA in the same buffer for $15 \mathrm{~min}$, dissected out, and postfixed overnight in the same fixative. Only the 4\% PFA fixed material was used in this study. Small blocks from the opercular surface of the occipital lobe and the dLGN were cut out and washed with $18 \%$ sucrose. The tissue was frozen and cut with a cryostat in coronal or tangential directions at a constant thickness of $40 \mu \mathrm{m}$. The distribution of PV and CB was studied by standard immunocytochemical methods using monoclonal antibodies directed against carp muscle PV produced by clone 235 (Celio et al., 1988), or against chicken gut $\mathrm{CB}$ produced by clone 300 (Celio et al., 1990). These antibodies are known to recognize monkey $\mathrm{PV}$ or $\mathrm{CB}$ respectively (Celio et al., 1988, 1990; Hendrickson et al., 1991; VanBrederode et al., 1990). For all immunocytochemical stainings, the sections were incubated free-floating on a shaker at $4^{\circ} \mathrm{C}$ for $72 \mathrm{~h}$, using the primary antibodies in a dilution of 1:5000 in Tris

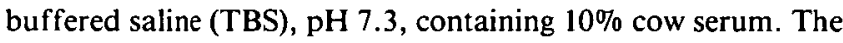
sections were then rinsed $6 \times 5 \mathrm{~min}$ in TBS, and further processed with the avidin-biotin complex (ABC) method of Hsu et al. (1981), using the Vectastain kit (Vector Laboratories, Burlingame, $\mathrm{CA}$ ). The antibody-enzyme complex was visualized using a solution containing $0.02 \% 3,3^{\prime}$-diaminobenzidine (DAB), and $0.006 \%$ hydrogen peroxidase in $0.05 \mathrm{M}$ TBS, pH 7.3. Nissl counterstaining was performed on a few immunostained sections out of each series, in order to visualize cortical layers and cytoarchitectonical boundaries. Afterwards, all sections were mounted on chrome-alum-coated slides, dehydrated in graded series of ethanol, cleared in xylol, and coverslipped in Eukitt ${ }^{\odot}$ (Gribi AG, CH-3123 Belb, Switzerland).

\section{Histochemistry}

Histochemistry for the mitochondrial enzyme $\mathrm{CO}$ (Wong-Riley, 1979) was carried out on some $40-\mu \mathrm{m}$-thick cryostat sections, adjacent to those processed for immunocytochemistry. In some sections, immunocytochemistry was carried out by using polyclonal antibodies directed against the holoenzyme CO (kindly provided by Dr. Kadenbach, Marburg, Germany). The staining patterns were similar, although staining with the antiserum was more reproducible after longer storage of the tissue blocks in $0.1 \mathrm{M}$ TBS, pH 7.3 containing $0.001 \%$ Na-azide.

\section{Quantitative analysis}

Serial sections cut in the coronal plane and thoroughly stained with $\mathrm{PV}$ and $\mathrm{CB}$ antibodies were used for the quantitative analyses. The numbers of heavily reactive cells were manually counted at a magnification of $600 \times$ using a $30 \times 30-\mu \mathrm{m}$ large ocular grid on a Zeiss microscope. For each section the grid was

Table 1. Use of animals (Macaca fascicularis and M. nemestrina)

\begin{tabular}{|c|c|c|c|c|}
\hline Subject & Weight & Experimental lesion & Survival time & Area analyzed \\
\hline M. fascicularis & $4.6 \mathrm{~kg}$ & none & - & Area $17, \mathrm{dLGN}$ \\
\hline M. fascicularis & $4.5 \mathrm{~kg}$ & none & - & Area 17, dLGN \\
\hline M. nemestrina & $6.6 \mathrm{~kg}$ & none & - & Area 17 \\
\hline M. nemestrina & $13 \mathrm{~kg}$ & right eye enucleation & 1 week & Area 17, left hemisphere \\
\hline M. nemestrina & $10.6 \mathrm{~kg}$ & right eye enucleation & 4 weeks & Area 17 , left hemisphere \\
\hline M. fascicularis & $3.5 \mathrm{~kg}$ & left eye enucleation & 10 weeks & Area 17, left hemisphere, dLGN \\
\hline M. fascicularis & $3.5 \mathrm{~kg}$ & right eye enucleation & 17 weeks & Area 17 , right hemisphere, dLGN \\
\hline
\end{tabular}

Only male animals were used for this study. The exact date of birth could not be determined, but the weight at sacrifice and the full dentation indicated that all were fully adult ( $>5$ years). dLGN: dorsal lateral geniculate nucleus. 
moved 50 times in adjacent columns perpendicular to the pial surface through all layers, so that a total cortical width of $1500 \mu \mathrm{m}$ was analyzed. By comparison with adjacent sections stained for $\mathrm{CO}$ activity, we assigned each vertical column sample to denervated or nondenervated ocular-dominance columns. Prominent blood vessels running vertically through the cortical depth served as landmarks for localization. The width of oculardominance columns (ODCs) was measured using a micrometer eyepiece with a digital counter (OSM-D4) attached to an Olympus microscope, and values were given as the mean \pm standard error of the mean (s.E.M.). For numerical analysis we used Excel $^{\circledast}$ and Stat View ${ }^{\circledR}$ software (Service Informatique, Université, CH-1705, Fribourg, Switzerland). Statistical significance was tested using the non-paired $T$-test between values of each animal. In a second series, tangential sections cut parallel to the cortical layers were analyzed. A $30 \times 30-\mu \mathrm{m}$ ocular grid was randomly placed within normal or denervated areas, as identified from adjacent CO-stained sections by photographic enlargements. For this analysis, we chose to study only those layers with the most obvious reduction patterns: for $P V$ we analyzed the cortical layer $4 C \beta$, for $C B$ layer 2 . We compared numbers of cells in denervated and non-denervated columns within the same animals using the two-sided paired $T$-test.

\section{Optical density measurements}

We estimated the content of immunoreactivity product in both the denervated and non-denervated ocular-dominance columns
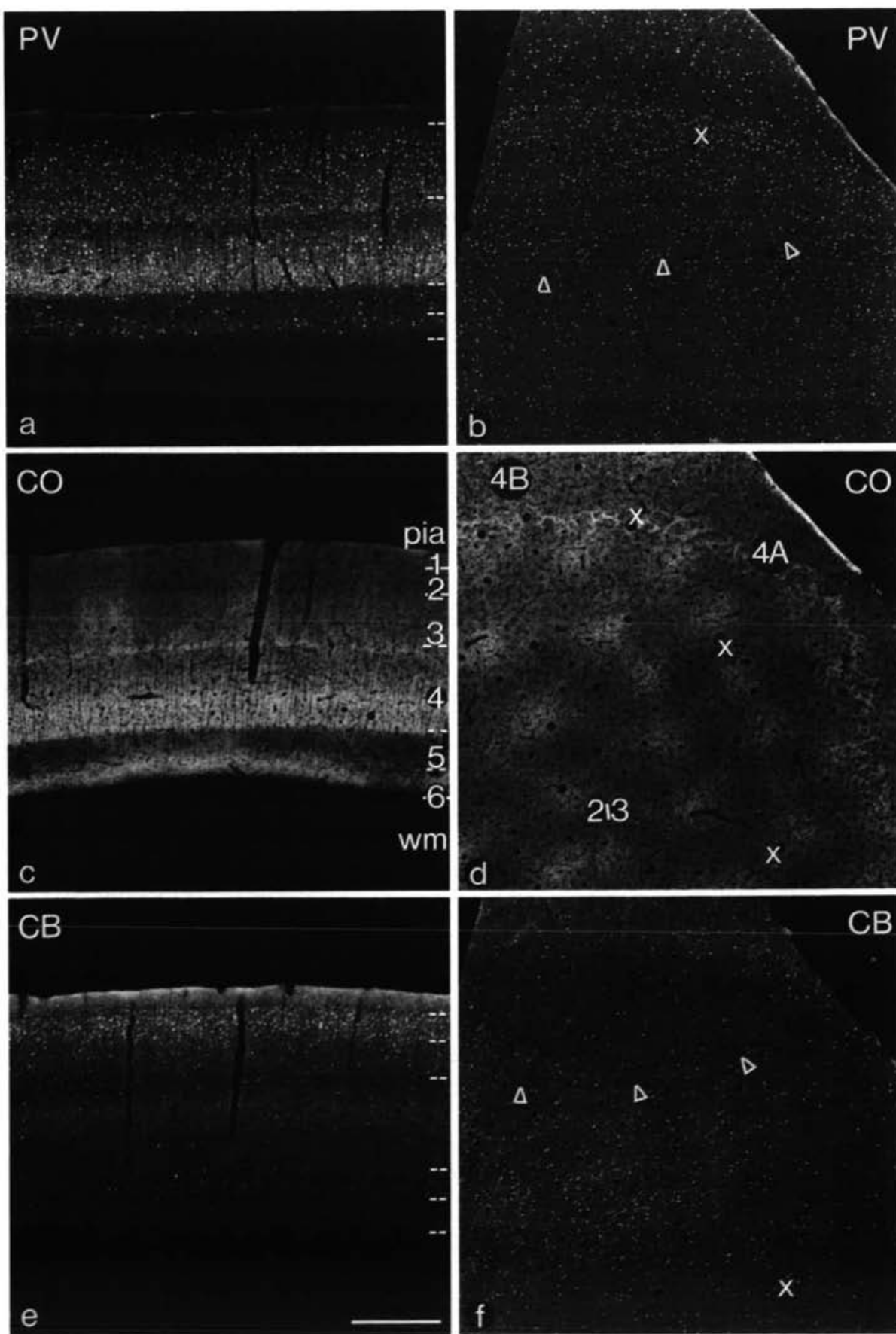
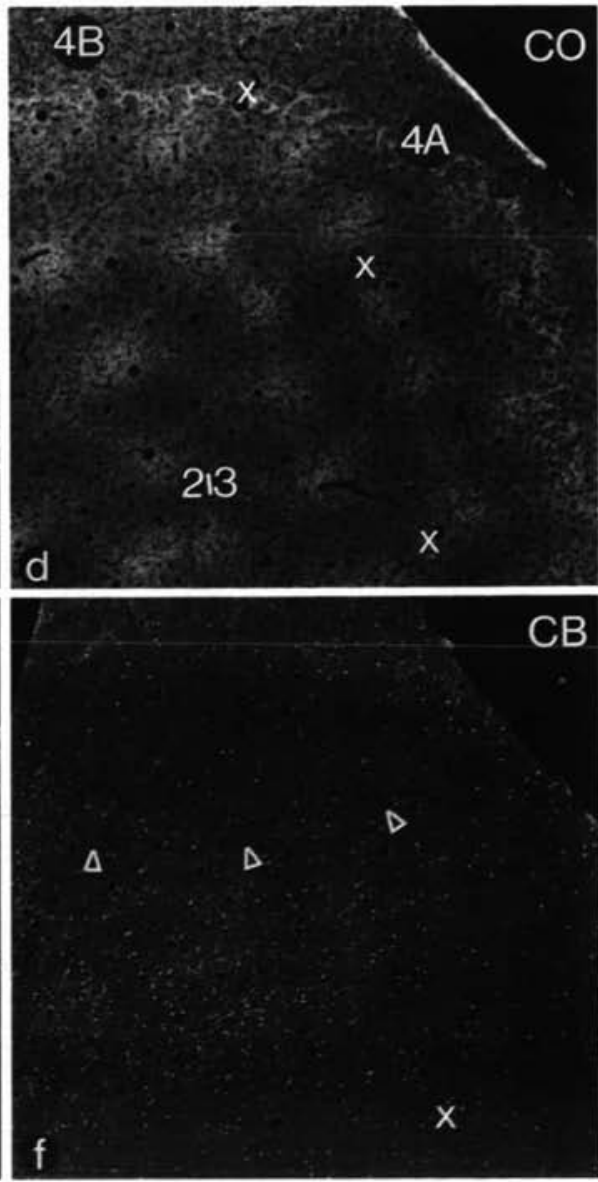

Fig. 1. Distribution of parvalbumin immunoreactivity (PV), cytochrome-oxidase histochemistry $(\mathrm{CO})$, and calbindin D-28k (CB) immunoreactivity in normal adult macaque monkeys. The sections were inserted into a photographic enlarger and directly printed, producing negative images of enhanced contrast (histographs). In this picture and Figs. 2, 3, and 5, the brown PV, $\mathrm{CB}$, and $\mathrm{CO}$ staining appears white. Lowpower histographs of adjacent coronal sections through area 17 of the operculum $(a, c, e$,$) . The histographs at the right side$ represent adjacent horizontal sections through the superficial layers $2 / 3$ up to $4 B$ of area 17. Although the neuropil labeling is weak, one can see, that PV-ir coincide with CO-rich blobs, whereas CB labeling alternates with them (arrowheads). $X$ indicates identical blood vessels. wm: white matter; pia: pial surface; and 1-6: cortical layers. Scale bar $=300 \mu \mathrm{m}$. 
$(\mathrm{ODC}-v s . \mathrm{ODC}+)$ by analyzing their different optical densities with the aid of a computerized image-acquisition system developed in the Institute of Histology. The measurements were performed on sections of the two animals with the longest survival time after enucleation. A CCD NXA 1011 camera mounted on a Leitz Diaplan microscope was connected to a Compaq 286 microcomputer. The image-processing program used was the Image-Pro II from Media Cybernetics. Each image was digitalized on 8 bits to a size of $512 \times 480$ pixels. The light source was provided by a mirror monochromator Leitz ${ }^{\oplus}$ (camera, microscope and equipment, and computer and software from Instrumatic, $\mathrm{CH}-8800$ Thalwil, Switzerland). We chose the illumination wavelength of $440 \mathrm{~nm}$ in order to obtain maximal contrast with the labeling used. Since all of the measurements were done on the same field of the computer screen and since we were only interested in the relative absorption values, flat-field and offset correction were unnecessary. We measured the optical densities of immunoreactivity staining patterns only in those layers showing the most obvious differences between ODC - and ODC+; PV-ir was measured within sublayer $4 C \beta, C B$-ir was measured within layers $2 / 3$. Adjacent sections, stained for $\mathrm{CO}$, were used for the identification of ODC+ and ODC - . We placed a $100 \times 140-\mu \mathrm{m}$ square showing the area of the optical density measurement, within the depicted layers and in the center of an ODC+ or ODC- of the computer image. The median of each measurement was registered. We compared only those values of ODC - with values of ODC + which derived from same series of immunohistochemical experiments on the same animals using the paired student's $T$-test and the StatView $^{\circledR}$ program (Service Informatique, Université, $\mathrm{CH}-1705$, Fribourg, Switzerland). For each series of measurements, we calculated the value for the optical density of the ODC- as a percentage of the value obtained for the ODC+. The percentages given in the text represent the mean from all different series of measurements.

\section{Results}

The specificity and the immunohistochemical distribution patterns of monoclonal antibodies against $\mathrm{PV}$ and $\mathrm{CB}$ in area 17 of normal adult macaque monkeys (Macaca fascicularis and Macaca nemestrina) have been described in detail by Blümcke et al. (1990) and VanBrederode et al. (1990). PV-ir neurons were scattered throughout the whole cortical thickness, with the exception of layer 1. A range of small to large multipolar and bitufted cells were stained. The largest number of neurons and the densest staining of the neuropil occurred in the geniculocortical recipient layers $4 C \beta, 4 C \alpha$, and $4 A$. The PV-ir staining pattern was in agreement with that obtained by $\mathrm{CO}$ histochemistry (Fig. 1). CB-ir neurons and neuropil of the primary visual cortex were much more sparsely distributed than PV-ir. CB-ir neurons were most frequent in the superficial layer 2 , with neuropil staining extending into layer 1 . A subpopulation of weakly stained small pyramidal cells also occurred in layer 2 . A second band of increased CB-ir nerve cells and neuropil occurred in layer $4 B$, and a third in layer 5 . On horizontal sections $C O$ rich blobs in layer 3 were slightly visible using both CaBPs (Fig.: 1); PV-ir neuropil was increased in the blob region, whereas CB-ir neuropil was richer in the interblob region. In contrast to studies using New World monkeys, there was no difference observed between the number of ir-cells in blob or interblob regions (VanBrederode et al., 1990).
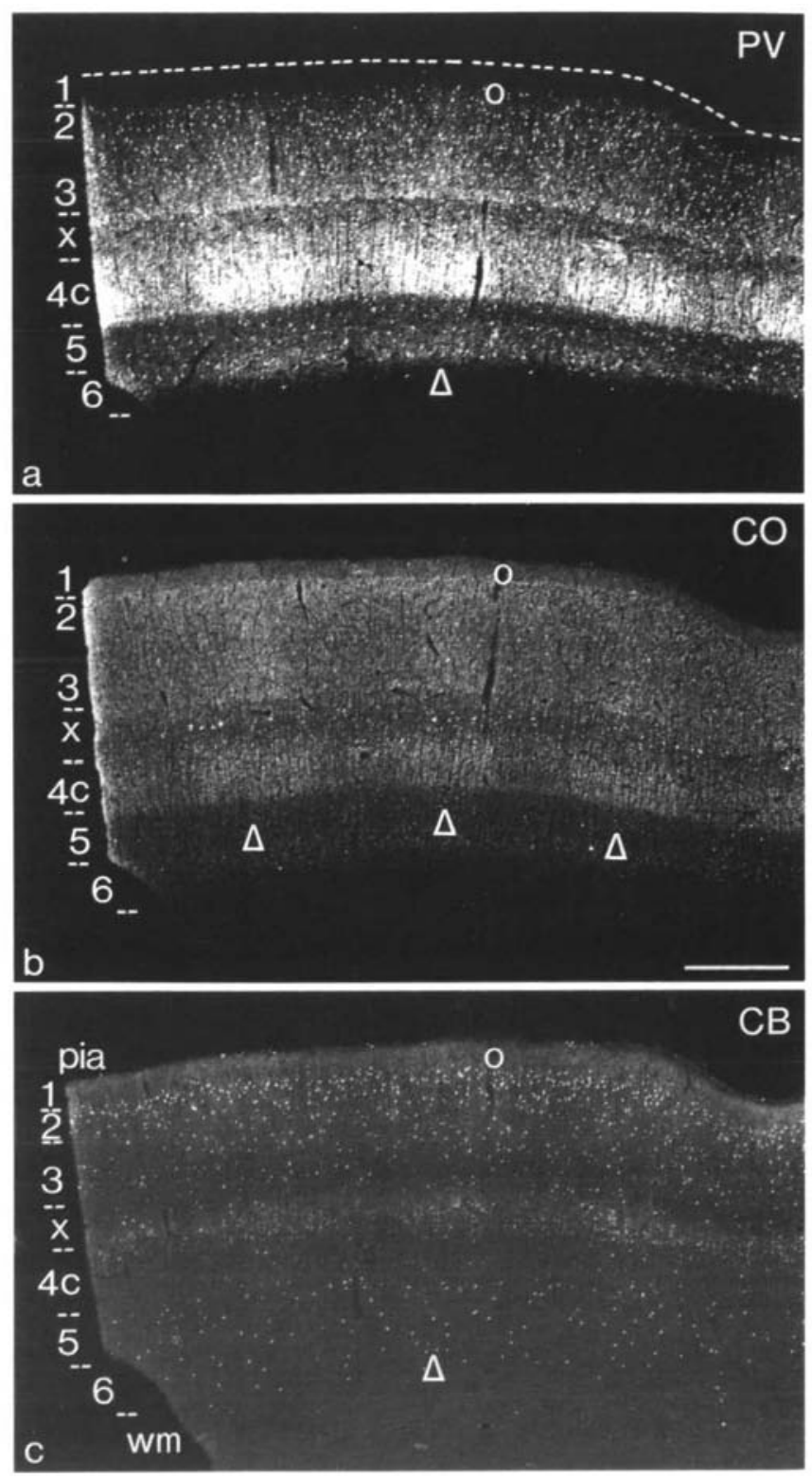

Fig. 2. Adjacent coronal sections through area 17 of an enucleated macaque monkey, which survived for 10 weeks after the lesion. (a) Parvalbumin immunoreactivity (PV). (b) Cytochrome-oxidase immunoreactivity (CO). (c) Calbindin D-28k immunoreactivity (CB). The reduction patterns of all three immunostainings overlap, as indicated by the arrowheads (o marks the identical blood vessels; the pial surface in (a) is indicated with a dotted line). 1-6: cortical layers; $x$ : includes the two layer 4 sublaminae $4 \mathrm{~A}$ and $4 \mathrm{~B}$; and $\mathrm{wm}$ : white matter. Scale bar $=300 \mu \mathrm{m}$.

\section{Parvalbumin immunohistochemistry in area 17 of monocularly enucleated animals}

The striate cortex of all enucleated monkeys showed strikingly reduced staining for the mitochondrial enzyme $\mathrm{CO}$ in the denervated ocular-dominance columns (ODCs). A decrease in $\mathrm{CO}$ staining was already detectable 1 week after eye enucleation. PV-ir was not changed at that time. The earliest reduction of PV-ir in the cortex occurred after a survival time of 1 month and became clearer with longer survival times. It was seen only 

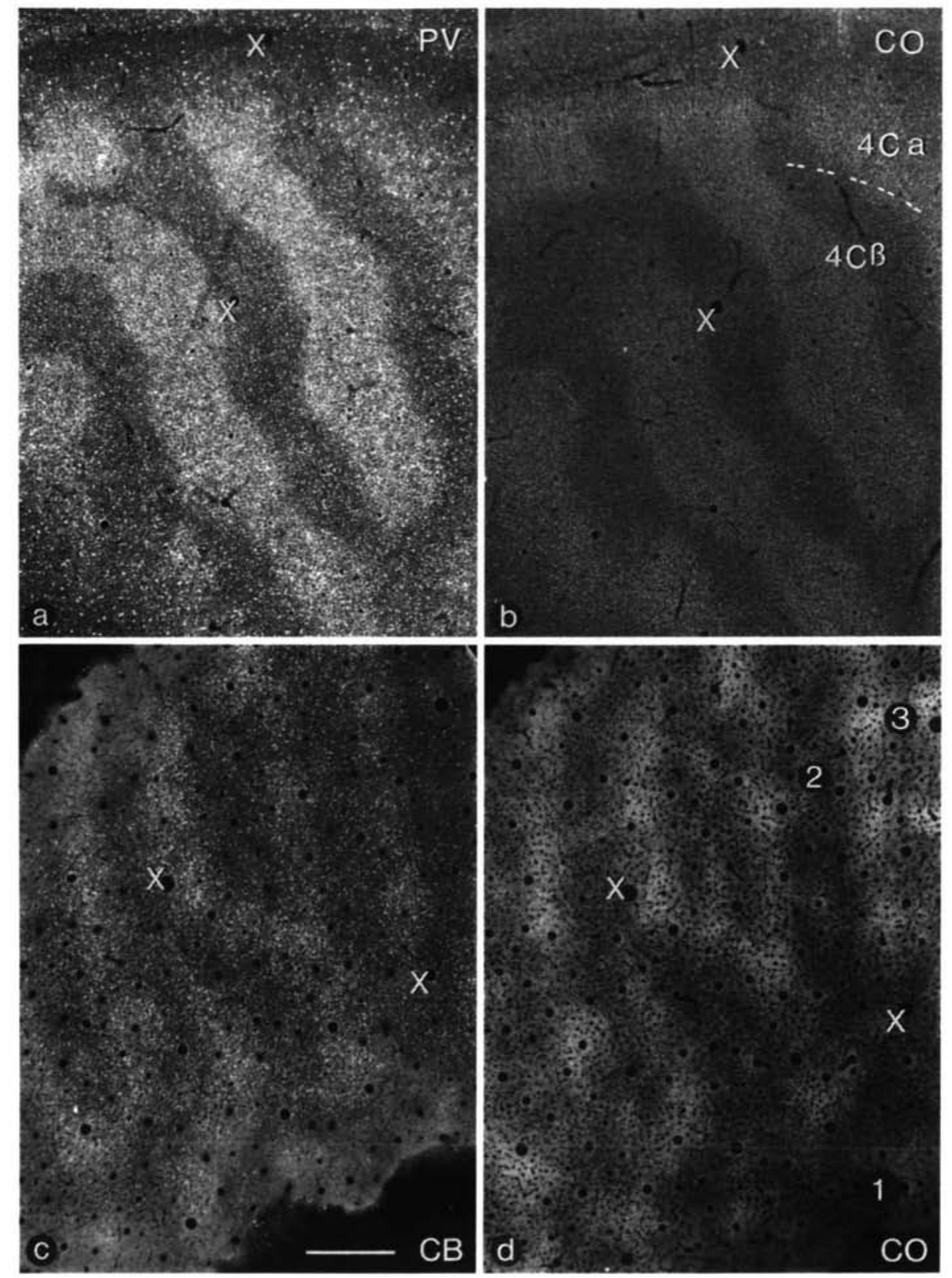

Fig. 3. Low-power histographs of tangential cut sections through the visual cortex of the same animal shown in Fig. 2 (10 weeks survival). (a) PV-immunoreactivity (ir) in layer $4 C \beta$ shows alternating bands of decreased ir, which coincide with enucleated-eye dominance columns (ODC-) of an adjacent section (b), stained for cytochrome oxidase-ir (CO). The number of PV-ir cells in the denervated columns is the same between ODC+ and ODC-. Identical blood vessels are indicated $(X)$. (c) Tangential section cut through the superficial layers of an enucleated monkey visual cortex and stained for $\mathrm{CB}$-ir. Alternating bands of decreased $\mathrm{CB}$-ir neuropil are visible in layers 1,2 , and 3 . Note that the number of CB-ir neurons is decreased in these bands. (d) Adjacent section stained for cytochrome-oxidase activity (CO). Scale bar $=300 \mu \mathrm{m}$. in the neuropil. This decrease of PV-ir neuropil occurred in vertically oriented columns and was restricted to the geniculocortical recipient layers $4 \mathrm{C}, 4 \mathrm{~A}, 3$, and 2 , as ascertained by comparison with $\mathrm{CO}$-labeled sections (Figs. 2 and 3 ). The most obvious reduction of $\mathrm{PV}$-ir neuropil was visible in sublayer $4 C \beta$. The optical density measurement performed in this sublayer revealed a decrease of immunoreactive staining product of $28.3 \%( \pm 2.2)$ in the ODC - compared to the adjacent ODC + (mean \pm S.E.M.; $P<0.0005$ ). Darkly stained PV-ir was often seen extending beyond columns lightly stained for $\mathrm{CO}$, usually as a thin rim at the very base of layer $4 C \beta$. In the animals with a survival time of 10 and 17 weeks, the width of lightly stained $P V$-ir columns in layer $4 C \beta$, measured in coronal sections, was smaller compared to the adjacent darkly labeled columns (10 weeks: $367.4 \mu \mathrm{m} \pm 15.2$ vs. $520.1 \mu \mathrm{m} \pm 14.1 ; 17$ weeks: $262.4 \mu \mathrm{m} \pm 9.0 v s .327 .0 \mu \mathrm{m} \pm 7.2$ ). Cell counts in two enucleated animals did not allow us to detect any reduction in the num- ber of PV-ir neurons within denervated ODCs (Table 2). The analysis of laminar cell counts even showed an increase of PVir cells in one animal at 10 weeks. We assume that this apparent increase was due to the easier identification of lightly labeled PV-ir cell bodies as the neuropil became less heavily stained following enucleation. In animals that survived longer than 10 weeks, the internal lamella of the white matter adjacent to the primary visual cortex, known to harbor projection fibers, contained fewer PV-ir fibers (Fig. 4).

\section{Calbindin D-28k immunohistochemistry in area 17 of monocularly enucleated animals}

Altered patterns of CB-ir occurred at 1 week after enucleation and also became clearer with time. The decrease in neuropil puncta staining occurred mainly in the superficial layer $2 / 3$, but the reduced labeling extended slightly into layers 1 , 


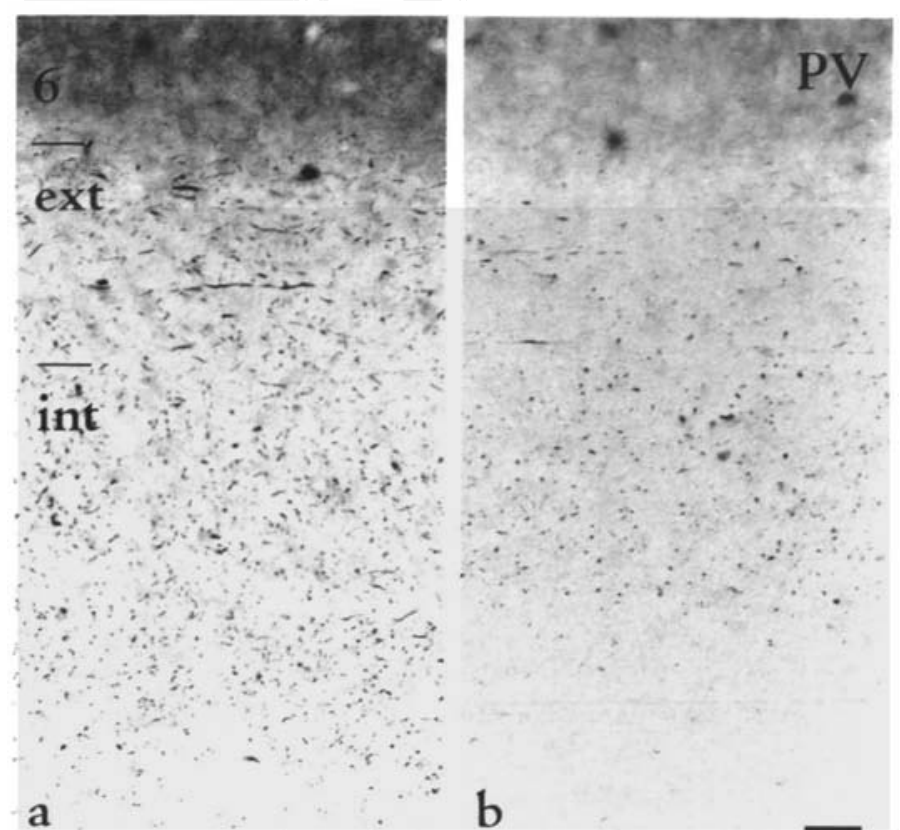

Fig. 4. In the internal lamella of the white matter adjacent to area 17 (Int), known to harbor projecting fibers, a reduction of PV-ir is visible. (a) In the animal with 1-week survival time both lamellae (Int \& Ext) contain amounts of PV-ir fibers, that are similar to normal adult monkeys (Blümcke et al., 1990). (b) After 10 weeks of monocular enucleation the number of PV-ir fibers in the internal lamella decreases. 6: cortical multiform layer; Ext: stratum sagittale externum; and Int: stratum sagittale internum. Scale bar $=40 \mu \mathrm{m}$.
$4 \mathrm{~B} / 4 \mathrm{C} \alpha$, and 5 , forming lighter vertically oriented columns (Fig. 5). These coexisted with the denervated ODCs when matched to CO-stained sections (Fig. 2). There was no difference between the width of $\mathrm{CB}$-ir denervated and nondenervated ODCs, as measured in layer $4 \mathrm{~B}(448.2 \mu \mathrm{m} \pm 12.5 v s .447 .8$ $\mu \mathrm{m} \pm 18.4$, respectively). Cell counts of CB-ir neurons in coronal sections throughout the total depth of the visual cortex of control and experimental animals revealed no significant changes in the overall cell number nor in the number of cells in denervated ocular-dominance columns (Table 2). Sublaminar analysis of enucleated cortices at 4,10 , and 17 weeks revealed lower numbers of $\mathrm{CB}$-ir neurons only at the border between sublayers $4 \mathrm{~B} / 4 \mathrm{C} \alpha$ (ODC+: $0.94 \pm 0.2$ cells $/ 30 \times 30 \mu \mathrm{m}$; ODC-: $0.6 \pm 0.24$ cells respectively; $0.005>P<0.01)$ and in superficial layers $2 / 3(O D C+: 1.2 \pm 0.04$ cells $/ 30 \times 30 \mu \mathrm{m}$; ODC - : $0.8 \pm 0.03$ cells $/ 30 \times 30 \mu \mathrm{m} ; P \leq 0.005$; Table 2 ). In the animals with the longest survival times, the lower neuropil staining in layers $2 / 3$ of the ODC - was estimated using a computerized optical density measurement and showed a significant decrease $(22.0 \% \pm 1.3$; mean \pm S.E.M. of percentages from individually analyzed sections; $P<0.0005$ ) compared to the adjacent ODC+.

\section{Immunoreactivity patterns in the dorsal lateral geniculate body (dLGN) of enucleated animals}

In normal adult macaque monkeys, PV-ir was found in the cell bodies and the neuropil of all parvocellular $(p)$ and mag. nocellular $(\mathrm{m})$ layers of the dLGN. CB-ir cell bodies occurred in clusters in the intercalated layers, more densely in layer $S$ and

Table 2. Number of CaBP immunoreactive neurons in area 17 of enucleated and normal control macaque monkeys

\begin{tabular}{|c|c|c|c|c|}
\hline \multirow[t]{2}{*}{ SUBJECT } & \multicolumn{4}{|c|}{ Average number of $\mathrm{CaBP}-$ ir cells in coronal sections* } \\
\hline & \multicolumn{2}{|c|}{$\alpha-\mathrm{PV} 235$} & \multicolumn{2}{|c|}{$\alpha-\mathrm{CB} 300$} \\
\hline CONTROLS & \multicolumn{2}{|c|}{$18.74 \pm 0.54$} & \multicolumn{2}{|c|}{$16.63 \pm 0.69$} \\
\hline \multirow[t]{3}{*}{$\begin{array}{l}\text { EXPERIMENTAL } \\
1 \text { week enucleated } \\
12 \text { weeks enucleated } \\
17 \text { weeks enucleated }\end{array}$} & $\begin{array}{c}\text { ODC+ } \\
19.72 \pm 0.54 \\
18.94 \pm 0.79\end{array}$ & $\begin{array}{c}\text { OCD- } \\
19.30 \pm 0.66 \\
21.84 \pm 0.67^{\mathrm{a}}\end{array}$ & $\begin{array}{c}\text { ODC+ } \\
14.57 \pm 0.62 \\
14.83 \pm 1.18 \\
13.92 \pm 0.47\end{array}$ & $\begin{array}{c}\text { ODC- } \\
12.72 \pm 0.77 \\
17.37 \pm 0.66^{\mathrm{a}} \\
16.14 \pm 0.78^{\mathrm{a}}\end{array}$ \\
\hline & \multicolumn{4}{|c|}{ Number of labelled cells in single layers $\dagger$} \\
\hline & \multicolumn{2}{|c|}{$\alpha$-PV 235 in $\mathrm{L} 4 \mathrm{C} \beta$} & \multicolumn{2}{|c|}{$\alpha-\mathrm{CB} 300$ in $\mathrm{L} 2 / 3$} \\
\hline $\begin{array}{l}\text { EXPERIMENTAL } \\
4 \text { weeks enucleated } \\
12 \text { weeks enucleated } \\
17 \text { weeks enucleated }\end{array}$ & $\begin{array}{c}\text { ODC+ } \\
1.15 \pm 0.04 \\
0.89 \pm 0.03\end{array}$ & $\begin{array}{l}\text { ODC }- \\
1.23 \pm 0.04 \\
1.25 \pm 0.40^{\mathrm{b}}\end{array}$ & $\begin{array}{r}\text { ODC+ } \\
0.38 \pm 0.02 \\
1.20 \pm 0.04 \\
0.76 \pm 0.03\end{array}$ & $\begin{array}{l}\text { ODC- } \\
0.28 \pm 0.02^{\mathrm{c}} \\
0.80 \pm 0.03^{\mathrm{c}} \\
0.65 \pm 0.03\end{array}$ \\
\hline
\end{tabular}

\footnotetext{
*Mean number ( \pm S.E.M.) of immunoreactive cells within $30 \mu \mathrm{m}$ thick cortical columns. We manually counted all heavily immunoreactive cells in vertical columns through the entire visual cortex. A $30 \times 30 \mu \mathrm{m}$ large ocular grid was moved 50 times on adjacent, parallel columns, perpendicular to the pial surface through all layers, analyzing a cortical field of $1500 \mu \mathrm{m}$. By comparing adjacent sections stained for CO activity, we assigned each vertical column sample whether it belonged to denervated (ODC-) or nondenervated (ODC + ) ocular dominance columns. The numbers of PV- and CB-ir cell bodies showed the tendency to increase in ODC - ( ${ }^{a}$ one way ANOVA $\left.0.005<P>0.01\right)$.

tOn tangential sections through area 17 , we randomly placed a $30 \times 30 \mu \mathrm{m}$ ocular grid within denervated and nondenervated ODCs, as identified from adjacent $\mathrm{CO}$ stained sections. For this analysis we only have chosen those layers with the most obvious neuropil reduction patterns: we analyzed PV in cortical layer $4 \mathrm{C} \beta(\mathrm{L} 4 \mathrm{C} \beta), \mathrm{CB}$ in layers $2 / 3(\mathrm{~L} 2 / 3) .{ }^{\mathrm{b}}$ An increase in PV-ir neurons in the ODC- of the animals studied a long time after enucleation was detected $(P<0.005) .^{c}$ In these animals weakly stained pyramidal cells occurred, which were likely the source of the decreasing numbers in the ODC $-(P<0.005)$.
} 

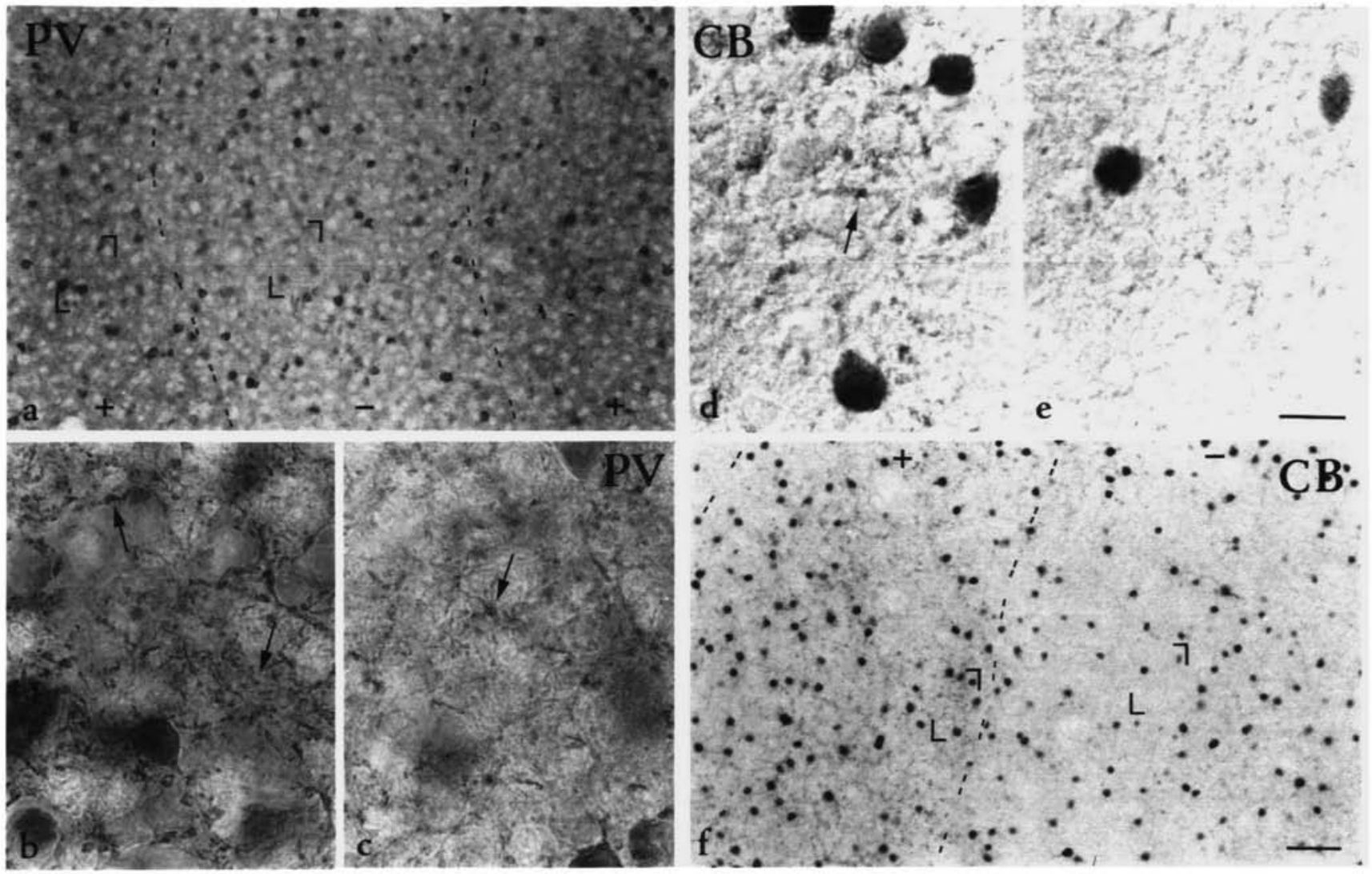

Fig. 5. Medium- and high-power magnification of $P V$-ir and $C B$-ir neuropil labeling of tangential cut sections through layers $4 C \beta(a-c)$ and layers $2 / 3(d-f)$, showing the significant reduction of stained neuropil in the denervated-eye ocular-dominance columns (e,c). The PV-ir puncta (arrows in $b$ and c) in layer $4 \mathrm{C} \beta$ mostly represent geniculocortical projection terminals (DeFelipe \& Jones, 1992; Jones \& Hendry, 1989). The higher magnification in b,c is taken from the boxed areas in a and d, e from $\mathrm{f}$, respectively. Scale bar in $\mathrm{f}(\mathrm{a})=50 \mu \mathrm{m}$; and in e (b-d) $=10 \mu \mathrm{m}$. Normarski optics in b-e.

moderately in the parvocellular and magnocellular layers (Fig. 6). The neuropil of the $m$ layers was most intensely CB-ir. We analyzed the dLGN of the two animals with the longest survival time (Table 1). Only PV-ir puncta were decreased in the neuropil of the denervated parvocellular and magnocellular layers, that is in layers 1,4 , and 6 of the right dLGN after left eye enucleation. The number of immunolabeled cells remained constant and their density did not decrease (Fig. 7). These results were consistent with those reported by Tigges and Tigges (1991) for macaque monkeys with similar survival times after monocular eyelid suture and enucleation. After eye removal CB-ir neurons were still detectable in the $S$ and intercalated layers (Fig. 6), but the labeling of CB-ir puncta in the neuropil was decreased in all denervated layers, as recently described by Mize et al. (1992a).

\section{Discussion}

We observed characteristic differences in the staining patterns of $\mathrm{PV}$ and $\mathrm{CB}$ in the dLGN and primary visual cortex of monocularly enucleated macaque monkeys. In the striate cortex, bands of decreased neuropil immunoreactivity alternated with normal staining in vertically oriented columns. Since the columns of decreased PV and CB immunoreactivity coincided with those demonstrating a loss of $\mathrm{CO}$ activity, they must represent a corresponding change in the denervated ocular-dominance columns (ODCs; Horton, 1984; Wong-Riley \& Carroll, 1984). A decrease in the neuropil staining of $P V$ and $C B$ was also found in the denervated layers of the dLGN as has been reported by Tigges and Tigges (1991) and Mize et al. (1992a).

Quantitative analysis of the densities of PV-ir neurons within denervated and nondenervated cortical ODCs revealed no changes in their number, even after a survival time of 4 months after monocular enucleation. From various neuroanatomical studies of the primate visual cortex, we know that PV is expressed in subpopulations of interneurons using the inhibitory neurotransmitter GABA (Celio, 1986; Hendry et al., 1989; VanBrederode et al., 1990). GABA-ir is decreased in cortical cell bodies as early as 4-5 days, and in the dLGN 3 weeks, after monocular enucleation (Hendry, 1991; Hendry \& Jones, 1986). PV seems, therefore, to represent a much more stable marker for these interneurons than their neurotransmitter. These results may also imply that PV is not directly involved in neurotransmission, but has a more basic role in the metabolism of the interneurons. Haseltine et al. (1979) have found a $20-30 \%$ decrease in the number of neurons in denervated columns more than a year after enucleation, but we suggest that PV-containing interneurons might be resistant to functional denervation and survive. This contention is supported by the findings of Hof et al. 

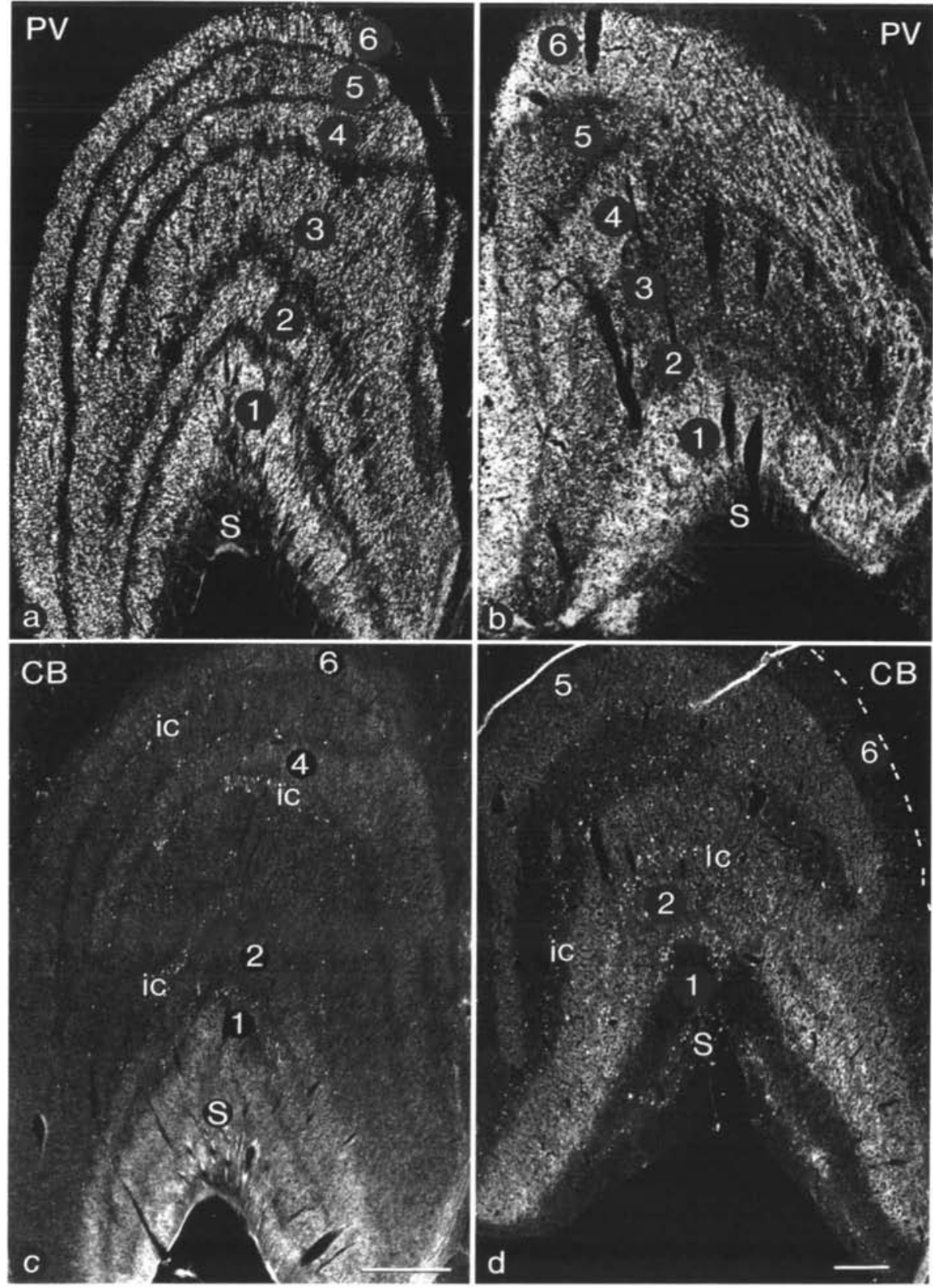

Fig. 6. Low-power histographs of CaBP immunoreactivity in the dLGN of a normal $(a, c)$ and a macaque monkey, that survived 10 weeks after enucleation of the left eye (b,d). Only the neuropil labeling shows a decrease in PV- and CB-ir in the denervated laminae (b: 2,3 , and 5 of the left dLGN; d: 1,4 , and 6 of the right dLGN), whereas the number of stained cells remains the same. 1-6: laminae of the $d L G N$; ic: intercalated laminae; and S: lamina S. Scale bars in $\mathrm{c}, \mathrm{d}=300 \mu \mathrm{m}$.
(1991) in Alzheimer brains, where the number of PV-ir interneurons remains unaffected in cortical areas deprived of cortico-cortical association fibers.

PV-ir neuropil labeling of puncta was decreased with time in the cortical layers $6,4 \mathrm{C} \alpha, 3$, and 2 , and most prominently, in layers $4 C \beta$ and $4 A$ of the denervated ODCs. This decrease was estimated semiquantitatively by measuring the optical densities between ODC + and ODC - and reached approximately $30 \%$ in the animals with the longest survival times after monocular enucleation. Since the numbers of heavily stained neuronal cell bodies did not change between the columns, we consider our data to reflect the decrease occurring in the neuropil. These cortical layers receive terminal inputs from geniculo-cortical projections (Hendrickson et al., 1978; Livingstone \& Hubel, 1982; Lund, 1988), many of which are PV-ir (Jones \& Hendry, 1989).
Asymmetric contacts in layers $4 \mathrm{C} \beta$ and $4 \mathrm{~A}$ have been shown to be PV-ir (Blümcke et al., 1991; DeFelipe \& Jones, 1991). Thus, the reduction in the neuropil staining of layers $4 \mathrm{C}$ and $4 \mathrm{~A}$ may be ascribed to the decrease of PV-ir in dLGN terminals. This is supported by the observation that axons in the internal lamella of the white matter, known to harbor projection fibers (Sachs, 1892), were less stained with PV antibodies in the enucleated animals. However, it can also be envisaged that terminals deriving from cortical PV-ir interneurons may contain less PV-ir.

We observed a reduction of approximately $20 \%$ of CB-ir in both neuropil labeling and in a small subset of pyramidal nerve cells, whereas the CB-ir persisted in the heavily labeled population of interneurons even after a survival time of 17 weeks. The CB-ir reduction correlated with $\mathrm{CO}$ reduction, indicating 


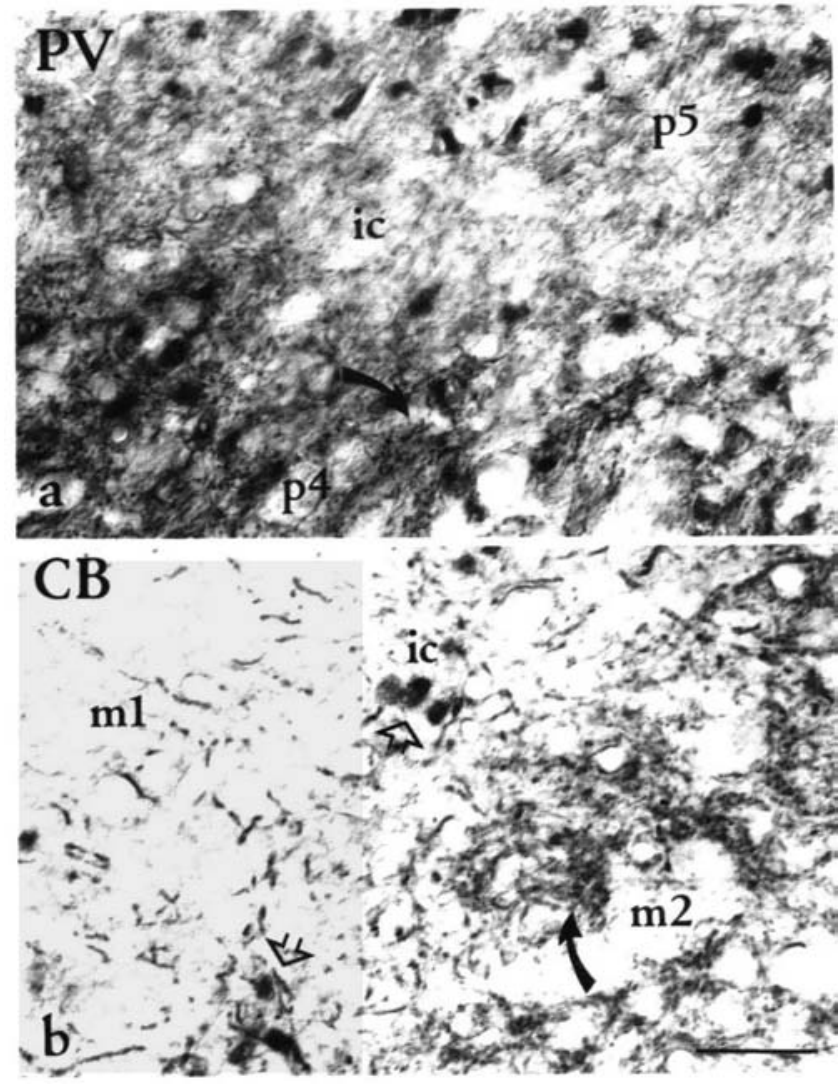

Fig. 7. High-power magnification of PIV-ir (a) and CB-ir (b) neuropil staining in the dLGN of the enucleated animal shown in Fig. $6 \mathrm{~b}$ and $\mathrm{d}$. (a) Like in normal adult animals, PV-ir neurons occur in both denervated $\mathrm{p} 5$ and nondenervated $\mathrm{p} 4$ laminae, whereas no ir-cells are found in the intercalated layer ic. Complementary, CB-ir neurons are only visible in the intercalated layers (open arrowheads in b; Jones \& Hendry, 1989). Note that the labeled puncta (arrows), representing synaptic boutons, are specifically decreased in the denervated laminae $(p 4, m 1)$, compared to the nondenervated laminae $(\mathrm{p} 5, \mathrm{~m} 2)$. $\mathrm{m} 1,2$ : magnocellular layers 1 and 2; and p4,5: parvocellular layers 4 and 5 . Scale bar $=$ $50 \mu \mathrm{m}$. Normarski optics.

that these changes were occurring in the enucleated ODCs. In general, CB antibodies heavily label GABA-ir cortical interneurons in layers $2 / 3$ which have vertical dendrites and axons (DeFelipe et al., 1990; VanBrederode et al., 1990). Thus, the decrease in CB-ir neuropil could result from a reduction in these vertical, locally restricted processes which are involved in translaminar information processing. The loss of $\mathrm{CB}$-ir in a distinct population of neurons was pronounced in the superficial layers 2 and $4 \mathrm{~B}$ of the denervated ODCs, where some of the weakly stained cells disappeared. Lightly labeled neurons have been shown to be pyramidal cells (Celio, 1990; Hendrickson et al., 1991; DeFelipe \& Jones, 1992), and the presence of mRNA for CB was confirmed with in-situ hybridization (Séquier et al., 1990). We could not differentiate between the down regulation of the intracellular protein concentration by functional inactivation of these cells and their disappearance. Hendrickson et al. (1991) and Hogan and Berman (1991) have shown that CB-ir has an extraordinarily long developmental time course. In monkey visual cortex, many pyramidal neurons are labeled before birth and waves of successive loss of CB-ir occur over the first 2-3 years after birth (Hendrickson et al., 1991). Perhaps denervation accelerates this normal trend, because the monkey with the longest survival time after enucleation was a young adult. These results may indicate that $C B$ in certain nerve cells is concerned with $\mathrm{Ca}^{2+}$-dependent functional processes, e.g. intracellular $\mathrm{Ca}^{2+}$ fluxes (Williams, 1992).

In recent studies, other authors have reported on differential effects of monocular enucleation or deprivation in respect to the immunohistochemical detection of CaBPs in subcortical and cortical visual areas in rat and monkey brain. In the deafferentiated superior colliculus (SC) of the rat, Schmidt-Kastner et al. (1992) described an increase in staining of PV in neurons and dendrites, whereas PV staining in fibers and axon terminals was decreased. Visual deprivation failed to reduce $\mathrm{CB}$-ir in rat and monkey SC (Mize \& Luo, 1992; Schmidt-Kastner et al., 1992), but was followed by significant reduction of PV-ir and CB-ir neuropil labeling in the deprived laminae of the dLGN (Mize et al., 1992a; Tigges \& Tigges, 1991). In the adult rat visual cortex, monocular deprivation had no effect on PV-ir, although a dramatic reduction occurred in the binocular portion of the developing rat visual cortex (Cellerino et al., 1992). This latter effect was shown to be due to competitive phenomena and not to visual deprivation itself (Cellerino et al., 1992). In agreement with our data, these results indicate that the expression of PV- and CB-ir is not directly determined by functional activity. The reason why the immunoreactivity in $\mathrm{dLGN}$ or cortical cell bodies is maintained, whereas the staining of axon fibers and terminals is decreased, is not immediately obvious. Deafferentiation may lead to a variety of morphological and biochemical changes occurring at various levels. Changes in the shape of the axonal boutons of geniculocortical projections have been reported in area 18 of the cat (Friedländer et al., 1991) and at the dendritic arborization of deafferentiated PV-ir interneurons in the hippocampus of the rat (Nitsch \& Frotscher, 1991). In addition, the breakdown of activity and release of substances at the synapse could alter the demands of CaBPs. Thus the CaBPs could redistribute centripetally towards the cell bodies.

In contrast to the mild changes reported here after monocular enucleation, PV-ir and CB-ir were heavily affected in the visual cortex of adult New and Old World monkeys after tetrodotoxin injections in one eye (Hendry \& Carder, 1992; and personal communication). In their qualitative description, these authors report a reduction of PV-ir in both neuronal and neuropil staining in the deprived ODCs and an increased staining of CB-ir in the interblob regions; those compartments which show low CB-ir immunoreactivity in normal adult animals. Intraocular tetrodotoxin injections reversibly block retinal ganglion cell action potentials (Wong-Riley \& Carroll, 1984), whereas eye enucleation irreversibly destroys retinal output pathways. The results, obtained from these two different experimental paradigms, are difficult to reconcile and further detailed studies using the same antibodies are necessary.

In conclusion, contrary to our expectations, enucleation does not abolish the expression of CB and PV in the deafferentiated compartments of the dLGN and visual cortex. Only the concentration of these proteins in the axons and terminals decreases. Thus, according to the results of these experiments, changes in functional activity only cause intracellular redistribution of the two proteins but do not alter their expression. 


\section{Acknowledgments}

We thank B. Blümcke, C. Dumas, and L. Schärer for their technical help, and Dr. D.M. Vogt for her constructive comments on the manuscript. The polyclonal antiserum against cytochrome oxidase was kindly provided by Dr. Kadenbach, Marburg, Germany. This study was supported by the Swiss National Foundation 31-27979.89 and NIH EY01208, EY04536 and in part by RR00166 to the Regional Primate Research Centre at the University of Washington.

\section{References}

Andressen, C., Blümcke, I. \& Celio, M.R. (1993). Calcium-binding proteins: Selective markers of nerve cells. Cell and Tissue Research 271, 181-208.

Baimbridge, K.G., Celio, M.R. \& Rogers, J.H. (1992). Calcium-binding proteins in the nervous system. Trends in Neuroscience 15, 303-308.

Blümcke, I., Hof, P.R., Morrison, J.H. \& Celio, M.R. (1990). Distribution of parvalbumin immunoreactivity in the visual cortex of Old World monkeys and humans. Journal of Comparative Neurology 301, 417-432.

BıümCKe, I., Hof, P.R., Morrison, J.H. \& Celio, M.R. (1991). Parvalbumin in the monkey striate cortex: A quantitative immunoelectron-microscopy study. Brain Research 554, 237-243.

BraUN, K. (1990). Calcium-binding proteins in avian and mammalian central nervous system: Localization, development, and possible functions. Progress in Histochemistry and Cytochemistry 21, 1-64.

CELIO, M.R. (1986). Parvalbumin in most $\gamma$-aminobutyric acid-containing neurons of the rat cerebral cortex. Science 231, 995-997.

Celio, M.R. (1990). Calbindin D-28k and parvalbumin in the rat nervous system. Neuroscience 35, 375-475.

Celio, M.R., Baier, W., Schärer, L., De Viragh, P.A. \& Gerday, C. (1988). Monoclonal antibodies directed against the calcium-binding protein parvalbumin. Cell Calcium 9, 81-86.

Celio, M.R., Baier, W., Schärer, L., Gregersen, H.J., de Viragh, P.A. \& Norman, A.W. (1990). Monoclonal antibodies directed against the calcium-binding protein calbindin D-28k. Cell Calcium 11, 599-602.

Celio, M.R., Schärer, L., Morrison, J.H., Norman, A.W. \& Bloom, F.E. (1986). Calbindin immunoreactivity alternates with cytochrome $\mathrm{C}$ oxidase-rich zones in some layers of the primate visual cortex. Nature 323, 715-717.

Cellerino, A., Sicillano, R., Domenici, L. \& Maffei, L. (1992). Parvalbumin immunoreactivity: A reliable marker for the effects of monocular deprivation in the rat visual cortex. Letters to Neuroscience 51, 749-753.

Chard, P.S., Bleakman, D. \& Miller, R.J. (1991). Parvalbumin is an intracellular $\mathrm{Ca}^{2+}$-buffering protein. Society of Neuroscience Abstracts 17, 343.

DeFelipe, J., Hendry, S.H.C. \& Jones, E.G. (1989). Visualization of chandelier cell axons by parvalbumin immunoreactivity in monkey cerebral cortex. Proceedings National Academy of Sciences of the U.S.A. 86, 2093-2097.

DeFelipe, J., Hendry, S.H.C., Hashikawa, T., Molinari, M. \& Jones, E.G. (1990). A microcolumnar structure of monkey cerebral cortex revealed by immunocytochemical studies of double bouquet cell axons. Neuroscience 37, 655-673.

DeFelipe, J. \& Jones, E.G. (1991). Parvalbumin immunoreactivity reveals layer-IV of monkey cerebral cortex as a mosaic of microzones of thalamic afferent terminations. Brain Research 562, 39-47.

DeFeliPE, J. \& JoNes, E.G. (1992). High-resolution light- and electronmicroscopic immunocytochemistry of colocalized GABA and calbindin D-28k in somata and double bouquet cell axons of monkey somatosensory cortex. European Journal of Neuroscience 4, 46-60.

Ferrer, I., Tú̃ón, T., Soriano, E., del Río, A., Iraizoz, I., Fonseca, M. \& GuIONNET, N. (1992). Calbindin immunoreactivity in normal human temporal neocortex. Brain Research 572, 33-41.

Friedländer, M.J., Martin, K.A.C. \& Wassenhove-McCarthy, D. (1991). Effects of monocular visual deprivation on geniculocortical innervation of area 18 in cat. Journal of Neuroscience 11, 3268-3288.

Haseltine, E.C., de Bruyn, E.J. \& Casagrande, V.A. (1979). Demonstration of ocular-dominance columns in Nissl-stained sections of monkey visual cortex following enucleation. Brain Research 176, 153-158.
Hendrickson, A.E., WiLson, J.R. \& OGRen, M.P. (1978). The neuroanatomical organization of pathways between the dorsal lateral geniculate nucleus and the visual cortex in Old World and New World primates. Journal of Comparative Neurology 182, 123-136.

Hendrickson, A.E., VanBrederode, J.F., Mulligan, K.A. \& Celio, M.R. (1991). Development of the calcium-binding protein parvalbumin and calbindin in monkey striate cortex. Journal of Comparative Neurology 307, 626-646.

HeNDRY, S.H.C. (1991). Delayed reduction in GABA and GAD immunoreactivity of neurons in the adult monkey dorsal lateral geniculate nucleus following monocular deprivation or enucleation. Experimental Brain Research 86, 47-59.

HENDRY, S.H.C. \& CARDER, R. (1992). Organization and plasticity of GABA neurons and receptors in monkey visual cortex. In $G A B A$ in the Retina and Central Visual System, ed. MIZE, R.R., MARC, R. \& Sillrto, A., pp. 477-502. Amsterdam: Elsevier Science Publishers.

HENDRY, S.H.C. \& JoNES, E.G. (1986). Reduction in number of immunostained GABAergic neurons in deprived-eye dominance columns of monkey area 17. Nature 320, 750-753.

HendRY, S.H.C. \& Jones, E.G. (1988). Activity-dependent regulation of GABA expression in the visual cortex of adult monkeys. Neuron 1, 701-712.

Hendry, S.H.C., Jones, E.G., Emson, P.C., Lawson, D.E.M., HeizMANN, C.W. \& Streit, P. (1989). Two classes of cortical GABA neurons defined by differential calcium-binding protein immunoreactivity. Experimental Brain Research 76, 467-472.

Hof, P.R., Cox, K., Young, W.G., Celio, M.R., Rogers, J. \& MorRISON, J.H. (1991). Parvalbumin-immunoreactive neurons in the neocortex are resistant to degeneration in Alzheimer's disease. Journal of Neuropathology and Experimental Neurology 50, 451-462.

Hogan, D. \& Berman, N.E.J. (1991). Calbindin-D is transiently expressed in pyramidal cells of neonatal kittens in an area-dependent pattern. Society of Neuroscience Abstracts 17, 367.

HoRTON, J.C. (1984). Cytochrome-oxidase patches, a new cytoarchitectonic feature of monkey visual cortex. Philosophical Transactions of the Royal Society B (London) 304, 199-253.

Hsu, S.M., Raine, L. \& Fanger, H. (1981). Use of avidin-biotinperoxidase complex $(\mathrm{ABC})$ in immunoperoxidase techniques: $\mathrm{A}$ comparison between $\mathrm{ABC}$ and unlabeled antibody (PAP) procedures. Journal of Histochemistry and Cytochemistry 29, 577-580.

JonEs, E.G. \& HENDRY, S.H.C. (1989). Differential calcium-binding protein immunoreactivity distinguishes classes of relay neurons in monkey thalamic nuclei. European Journal of Neuroscience 1, 222-246.

Kawaguchi, Y., Katsumaru, H., Kosaka, T., Heizmann, C.W. \& HaMA, K. (1987). Fast spiking cells in rat hippocampus (CA1 region) contain the calcium-binding protein parvalbumin. Brain Research 416, 369-374.

KöHR, G., LAMBert, C.E. \& MOdY, I. (1991). Calbindin-D28K (CaBP) levels and calcium currents in acutely dissociated epileptic neurons. Experimental Brain Research 85, 543-551.

LEWIS, D.A. \& LUND, J.S. (1990). Heterogeneity of chandelier neurons in monkey neocortex: Corticotropin-releasing factor- and parvalbumin-immunoreactive populations. Journal of Comparative Neurology 293, 599-615.

LivingSTONE, M.S., HuBEL, D.H. (1982). Thalamic inputs to cytochrome oxidase-rich regions in monkey visual cortex. Proceedings National Academy Sciences of the U.S.A. 79, 6098-6101.

LUND, J.S. (1988). Anatomical organization of macaque monkey striate visual cortex. Annual Review of Neuroscience 11, 1062-1075.

Mize, R.R. \& Luo, Q. (1992). Visual deprivation fails to reduce calbindin $28 \mathrm{kD}$ or GABA immunoreactivity in the Rhesus monkey superior colliculus. Visual Neuroscience 9, 157-168.

Mize, R.R., Luo, Q. \& Tigges, M. (1992a). Monocular enucleation reduces immunoreactivity to the calcium-binding protein calbindin $28 \mathrm{kD}$ in the Rhesus monkey lateral geniculate nucleus. Visual Neuroscience 9, 471-482.

Mize, R.R., Luo, Q., Butler, G.D., Jeon, C.J. \& NABors, B. (1992b). The calcium-binding proteins parvalbumin and calbindin-D-28K form complementary patterns in the cat superior colliculus. Journal of Comparative Neurology 320, 243-256.

NitsCh, R. \& FrotsCher, M. (1991). Maintenance of peripheral dendrites of GABAergic neurons requires specific input. Brain Research 554, 304-307.

SACHS, H. (1892). Das Hemisphärenmark des menschlichen Grosshirns, 1. Der Hinterhauptslappen. Leipzig: Georg Thieme. 
SChmidt-Kastner, R., Meller, D. \& Eysel, U.T. (1992). Immunohistochemical changes of neuronal calcium-binding proteins parvalbumin and calbindin-D-28k following unilateral deafferentiation in the rat visual system. Experimental Neurology 117, 230-246.

Séquier, J.M., Hunziker, W., Andressen, C. \& Celio, M.R. (1990). Calbindin D-28k protein and mRNA localization in the rat brain. European Journal of Neuroscience 2, 1118-1126.

Spatz, W.B., Illing, R.B. \& Vogt, D.M. (1992). Cytochrome-oxidase blobs, parvalbumin- and calbindin-like immunoreactivity in area 17 of New and Old World monkeys. European Journal of Neuroscience (Suppl). 5, 260.

Tigges, M. \& Tigges, J. (1991). Parvalbumin immunoreactivity of the lateral geniculate nucleus in adult rhesus monkeys after monocular eye enucleation. Visual Neuroscience 6, 375-382.

VanBrederode, J.F., Mulligan, K.A. \& Hendrickson, A.E. (1990). Calcium-binding proteins as markers for subpopulations of GABA- ergic neurons in monkey striate cortex. Journal of Comparative Neurology 298, 1-22.

Wiesel, T.N. \& Hubel, D.H. (1965). Comparison of the effects of unilateral and bilateral closure on cortical unit responses in kittens. Journal of Neurophysiology 28, 1029-1040.

Williams, R.J.P. (1992). Calcium fluxes in cells: New views on their significance. Cell Calcium 13, 273-275.

Willams, S.M., Goldman-Rakic, P.S. \& Leranth, C. (1992). The synaptology of parvalbumin-immunoreactive neurons in the primate prefrontal cortex. Journal of Comparative Neurology 320, 353-369.

WoNG-RILEY, M.T.T. (1979). Changes in the visual system of monocularly sutured or enucleated cats demonstrable with cytochromeoxidase histochemistry. Brain Research 171, 11-28.

Wong-RILEY, M.T.T. \& CARRoll, E.W. (1984). Effect of impulse blockage on cytochrome-oxidase activity in monkey visual cortex. Nature 307, 262-264. 
